\title{
Teachers' Views towards the Effects of Covid-19 Pandemic in the Education Process in Turkey
}

\author{
Ferhat Karakaya* \\ Yozgat Bozok University, Yozgat, ORCID: https://orcid.org/0000-0001-5448-2226
}

Merve Adigüzel

Gazi University, Gazi Education Faculty, Maths and Science Education Department, Biology

Education, Ankara, ORCID: https://orcid.org/0000-0003-2462-0231

Gökşen Üçüncü

National Ministry of Education, Istanbul, Turkey; ORCID: https://orcid.org/0000-0001-8107$229 X$

\section{Osman Çimen}

Gazi University, Gazi Education Faculty, Maths and Science Education Department, Biology Education, Ankara, Turkey; ORCID: https://orcid.org/0000-0002-6651-6849

\section{Mehmet Yilmaz}

Gazi University, Gazi Education Faculty, Maths and Science Education Department, Biology Education, Ankara, ORCID: https://orcid.org/0000-0001-6700-6579

\begin{tabular}{|c|c|}
\hline Article history & Viruses cause disease in both animals and plants. New viral diseases are \\
\hline $\begin{array}{l}\text { Received: } \\
13.06 .2020\end{array}$ & $\begin{array}{l}\text { often caused by the spread of existing viruses from one host species to } \\
\text { another. The COVID-19 pandemic has been spreading across the world }\end{array}$ \\
\hline $\begin{array}{l}\text { Received in revised form: } \\
16.11 .2020\end{array}$ & $\begin{array}{l}\text { since its emergence in China. The pandemic affected not only the health } \\
\text { systems of the countries but also their education systems. To prevent the } \\
\text { spread of the epidemic, schools were closed, and different practices were }\end{array}$ \\
\hline $\begin{array}{l}\text { Accepted: } \\
17.11 .2020\end{array}$ & $\begin{array}{l}\text { presented in this period. In this study, it was aimed to determine the } \\
\text { teachers' views towards the effects of COVID-19 on the education }\end{array}$ \\
\hline Key words: & process in Turkey. The case study was used in the research and it was \\
\hline $\begin{array}{l}\text { Covid-19, } \\
\text { pandemic, } \\
\text { education, } \\
\text { teachers, } \\
\text { effect of covid-19 }\end{array}$ & $\begin{array}{l}\text { carried out with the participation of } 237 \text { different branch teachers. In } \\
\text { order to collect the data, structured interview form prepared by the } \\
\text { researchers was used. Data were evaluated by using the content analysis } \\
\text { technique. As a result of the research, it was determined that teachers } \\
\text { have both positive and negative views about competencies, distance } \\
\text { education, adaptation of students and teacher-parent communication. In } \\
\text { addition, it was determined that teachers have varying concerns about } \\
\text { health, economy and education. On the other hand, research results also } \\
\text { have shown that the pandemic process provides positive acquisitions in } \\
\text { technology use, awareness and skill development. }\end{array}$ \\
\hline
\end{tabular}

\footnotetext{
* Correspondency: ferhatk26@gmail.com
} 


\section{Introduction}

With the increasing population around the world, human needs have increased, and they have expanded their living spaces. This situation has caused people to be in more contact with animals in wildlife other than pets than in the past. Many animals, whose own habitat has been destroyed, share the same environment as humans. When the factors of many diseases that have emerged in recent years are examined, it is seen that there are viruses from animals. Viruses cause disease in both animals and plants. New viral diseases are often caused by the spread of existing viruses from one host species to another. For example, an influenza-like disease pandemic occurred in 2009 in Mexico and the USA. The infectious agent that is effective in the formation of this disease was quickly identified as a flu virus called H1N1 in relation to those that cause seasonal flu. The disease spread rapidly worldwide and turned into a global epidemic that infected more than 600,000 people in 207 countries. The H1N1 virus probably passed on to humans after many years of wandering among pigs. In fact, the scientific world estimates that about three-fourths of new human diseases are caused by other animals (Taylor et al., 2018, p.205-206). In 2019, a rapidly spreading fatal disease emerged in Wuhan, China (Rasmussen et al., 2020). This disease was identified as the new coronavirus (2019-nCoV) by the World Health Organization (WHO) in 2019 (Wang, Wang, Chen, \& Qin, 2020). In the subsequent process, the new coronavirus pneumonia was called "COVID-19" (coronavirus disease 2019) (WHO, 2020). The causative agent of this disease is an RNA virus from the coronavirus family, with envelope, single chain and positive polarity (Çobanoğlu, 2020). Coronaviruses with an envelope (outer sheath) enter the cell by binding their glycoproteins to specific sensing molecules which are on the surface of the host cell (Madigan et al., 2019, p.313; Reece et al., 2017, p.404-405). Coronaviruses cause respiratory infections in humans and other animals, including about $15 \%$ common colds and SARS, which sometimes causes fatal infection of the lower respiratory tract in humans (Madigan et al., 2019, p.325).

Fatal diseases do not have geographical boundaries (Çobanoğlu, 2020), so, global measures should be taken to solve the problem. Restrictive measures are necessary to optimize the quality of healthcare provided to COVID-19 patients and to reduce the risk of viral transmission to other patients or healthcare workers (Wong et al., 2020). Restrictive measures have been taken to reduce the spread of pandemics around the world, such as curfews, the use of masks and the closure of businesses. March 10, 2020, the first cases in Turkey Covid-19 have been identified. Ministry of Health has announced closure, partial closure or social distance measures for places where people are busy such as airports, blood centers, accommodation facilities, public transportation vehicles, restaurants, markets and bank branches. In addition, a list of suggestions was published by the Ministry of Health in order not to catch COVID-19 disease. According to this list; It is recommended to pay attention to hand cleaning, to maintain social distance, to minimize contact, to pay attention to food habits and to follow the quarantine period after travel (Ministry of Health, 2020).

COVID-19, which is spreading around the world, has affected education systems as well as many fields (health, economy, etc.). It is estimated that the closure of schools in the COVID19 pandemic process affected more than 1.5 billion students and 63 million educators in 188 countries to date (UNESCO, 2020; Özer, 2020). Considering the students, teachers and their families in the education system, millions of people are at risk of being affected by the pandemic. To reduce this risk, US, China, England, Germany, Turkey and Italy are amongst the countries that take measures of relatively more immediate or effective nature regarding the teaching-learning processes. For example, all students from kindergarten to postgraduate 
education were asked to stay at home in China and education has been carried out through online systems to reduce the spread of pandemics. Italy, one of the countries most affected by the pandemic, has temporarily closed educational institutions to prevent further spread of coronavirus as of March 4, 2020. The UK Government adopted the understanding of social immunity at the beginning of the epidemic. For this reason, schools in England are not closed. However, due to the increase of the pandemic throughout England, transition to distance education has started in education. Some universities in the US (Ohio State, Harvard, Duke, Columbia, Tufts) have interrupted face-to-face classroom classes (Yamamoto, 2020). In the following process, different measures (closure of schools, online applications etc.) were taken across the country. In Turkey, measures to reduce the impact of the pandemic on the teachinglearning process emerged in a quick sense and formal education has been suspended by the Ministry of Education (MoNE) and The Council of Higher Education (CoHE) due to COVID19. On 16 March 2020, the MoNE announced that face to face education was interrupted in primary and secondary education institutions. On March 23, 2020, it was announced by the MoNE that distance education started. The Ministry of Education and Turkey Radio and Television Corporation (TRT) was performed their cooperation. As a matter of fact, with the cooperation of these two institutions, three different television channels were opened to provide distance education. In addition, the Ministry of Education has increased the capacity of EBA's (please provide the actual name not the acronym only) education platform in Turkey and has provided support to distance education (Özer, 2020). Today education in Turkey is carried out using different applications via distance education. In higher education, education was interrupted for a short time in the first place. Later, it is announced that the spring term of 2020 will be completed by distance education (The Council of Higher Education, 2020).

When the studies on the COVID-19 pandemic are examined, it is seen that it is concentrated in the field of health (Saglam, Kanoglu, Guler \& Ceyhan, 2020). In addition, there are studies in the literature that examine the economic effects of the COVID-19 pandemic (Kanoglu \& Saglam, 2020). For example, in the research conducted by Acar (2020), the effects of the new coronavirus pandemic (COVID-19) on tourism were determined. As a result of the research, it has been determined that the pandemic will have negative effects on the national economies for a long time. Ayittey et al. (2020) stated that as a result of their research, China will have huge economic losses due to this epidemic. Similar studies have been found about the effects of the COVID-19 pandemic on the economy both nationally and internationally (Leduc \& Liu, 2020; Matteo, \& Pianta, 2020; Rani, 2020). In his research, Çobanoğlu (2020) stated that COVID-19 pandemic is a process that re-questions the ethical perspective in many areas. However, it has been determined in the literature that there are not enough studies for the education-training process. In the study conducted by Bakioğlu and Çevik (2020), it was determined that science teachers did not have enough information about the pandemic. In addition, it was determined that science teachers have different problems (internet connection, communication, student participation rate, etc.) in distance education. In the study conducted by Tümkan and Tümkan (2020), it was unearthed that education provided during the Covid19 pandemic had negative effects on students. In the study by Karakaya, Arık, Çimen, and Y1lmaz (2020), the views of biology teachers about distance education were examined. As a result of the research, it has been accentuated that distance education increases technology use, cooperation, empathy and positive thinking toward lessons.

Determining the effects of the epidemic experienced worldwide on education systems is highly crucial for the future of the educational process. In fact, examining the effects of a pandemic in terms of students, teachers and parents will be a reference for measures to be taken in similar situations. In addition, determining the effects of such pandemics will be 
important for the integration of technology into education. In Turkey, in order to minimize the impact of COVID-19 pandemic on students, teachers have taken great responsibility. In this process, teachers support their students both in terms of education and psychology. Therefore, their views are important to determine the effects of the COVID-19 pandemic on the educational process. In this research, it was aimed to determine the effects of COVID-19 on the education process in Turkey according to teachers' views. In line with the purpose of the research, the educational process was examined in terms of teacher, student, teacher-parent relationship, and teacher concerns. An answer was sought to the question "What are the teachers' views on education in the COVID-19 pandemic process?"

\section{Method}

\section{Research model}

The case study model was used in this research. Case study refers to the detailed explanation of the situation or events that take place within a system (Creswell, 2007). The biggest benefit of case studies is that it focuses on the multi-faceted and in-depth analysis of the subject that is to be investigated (Yılmaz, Çimen, Karakaya \& Üçüncü, 2018). In this research, the case study was used in order to investigate the subject to be investigated in-depth and in multifaceted way.

\section{Study group of the research}

The study group of the research consists of 237 teachers who work in different provinces and institutions in Turkey. The research was carried out in the spring semester of the 2019-2020 academic years. On the title page of the form, the participants were informed about the purpose of the research. In addition, informed consent forms were obtained from the participants through the form. Demographic information of the teachers participating in the research is given in (Table 1).

Table 1. Demographic information of the teachers

\begin{tabular}{llll}
\hline Demographic Information & & $\mathrm{N}$ & $\%$ \\
\hline \multirow{2}{*}{ Gender } & Female & 174 & 73.4 \\
& Male & 63 & 26.6 \\
\hline \multirow{2}{*}{ Institution } & Public school & 95 & 40.1 \\
& Private school & 142 & 59.9 \\
\hline \multirow{2}{*}{ Education level } & Undergraduate & 157 & 66.2 \\
& Graduate & 80 & 33.8 \\
\hline \multirow{2}{*}{ Professional experience } & $0-1$ year & 21 & 8.9 \\
& $1-3$ years & 27 & 11.4 \\
& $3-5$ years & 48 & 20.3 \\
\multirow{2}{*}{ School type } & 5 years and up & 141 & 59.5 \\
& Elementary school & 30 & 12.7 \\
\end{tabular}

\section{Data collection and Analysis}

Structured interview form prepared by the researchers was used for the collection of the data. Opinions were received from two (2) different field experts for the validity of the semi-structured interview form. The form, which was prepared as 5 questions, was turned into 
4 questions after receiving expert opinions. The final version of the form was created by making necessary corrections in terms of language and content. The semi-structured interview form consists of two parts. In the first part, there are questions to determine the demographic information of the teachers. In the second part, there are four (4) different questions prepared for the purpose of the research. In the data collection process, https://docs.google.com/forms system was used. The link of the prepared form was shared with the teachers via e-mail. The teachers were informed that the ethical rules will be adhered to and the participation is based on voluntariness. The forms answered by teachers (T-1, T-2, T-3, etc.) were coded.

The data were evaluated through content analysis. Content analysis is defined as the systematic coding of quantitative or qualitative data within the framework of certain themes and classifications (Cohen, Manion \& Morrison, 2007; Fraenkel, Wallen \& Hyun, 2012). Content analysis allows the data to be classified under certain themes to reveal their relationship (Yıldırım \& Şimşek, 2011, p.227). For this reason, the analysis of the data was carried out with inductive content analysis. Each data was first read by two different researchers and an integrated understanding was attempted to create. Sub-themes, themes and categories were determined according to the codes formed as a result of content analysis. In order to determine whether there is consistency between the researchers, the formula of Reliability =Consensus/All opinions put forward by Miles and Huberman (2015) was applied. Reliability value of the two coders was calculated as $91 \%$.

\section{Result}

The findings obtained in the research are presented in this section. In the research, the education process in the COVID-19 pandemic was first evaluated in terms of teachers. The findings obtained are given in (Table 2).

Table 2. Assessment of the COVID-19 pandemic process from the points of teachers

\begin{tabular}{|c|c|c|c|c|}
\hline Category & Theme & Sub-theme & $\mathrm{f}$ & $\%$ \\
\hline \multirow{12}{*}{ Negative } & \multirow{6}{*}{$\begin{array}{l}\text { General assessment of } \\
\text { the process }\end{array}$} & The difficulty of the process & 68 & 28.7 \\
\hline & & Inability to complete the curriculum & 9 & 3.8 \\
\hline & & Inability to measure and evaluate & 3 & 1.3 \\
\hline & & Uncertainty & 5 & 2.1 \\
\hline & & Content quality & 3 & 1.3 \\
\hline & & Financial loss & 4 & 1.7 \\
\hline & \multirow{6}{*}{ Distance Education } & Poor interaction & 16 & 6.8 \\
\hline & & Unproductive & 15 & 6.3 \\
\hline & & Time-consuming & 4 & 1.7 \\
\hline & & Failure to ensure control process & 6 & 2.5 \\
\hline & & Inadequate technological infrastructure & 7 & 3.0 \\
\hline & & Teacher's lack of technological competence & 7 & 3.0 \\
\hline \multirow{4}{*}{ Positive } & \multirow{2}{*}{$\begin{array}{l}\text { General assessment of } \\
\text { the process }\end{array}$} & Supporting skill development & 19 & 8.0 \\
\hline & & Use of technology & 26 & 11.0 \\
\hline & \multirow{2}{*}{ Distance Education } & Time management/productivity & 9 & 3.8 \\
\hline & & Continuity & 36 & 15.2 \\
\hline
\end{tabular}

When the findings in Table 2 are analysed, it was determined that the education process in the COVID-19 pandemic has positive and negative issues regarding competencies and distance education in terms of teachers. The intensity of negative views is remarkable in terms of difficulty $(28.7 \%)$ and poor interaction $(6.8 \%)$. However, the teachers stated that education in the pandemic process was positive in terms of technology use (15.2\%) and continuity (15.2\%). Sample opinions that were originally Turkish and translated into English by an 
expert on the negative effects of the COVID-19 pandemic process for teachers are given below:

T-3: I don't have any technological knowledge to apply distance education. T-13: We don't know whether we will get paid our salaries. T-19: I do not think that teachers are as efficient as at school because there is no internet in every student's home. T-30: I can easily explain topics in face-to-face education, but I have difficulty in explaining the topics in distance education. T-48: It is obvious that education cannot be productive without face-to-face education with our students. T-64: Distance education prevents learning by doing-living. T-170: Since the COVID-19 process is an unexpected process, we are left behind the curriculum. T-211: Uncertainty of education process is a sorrow for all of us.

Sample opinions on the positive effects of the COVID-19 pandemic process for teachers are given below:

T-23: Our teachers have been doing their best in order for the education to continue. T28: It was an instructive process in terms of being familiar with new teaching methods. T41: This process was an opportunity for teachers to overcome their deficiencies. T-42: Teachers understood the importance of distance education. Awareness of teachers regarding the use of technology has increased. T-180: I think that the pandemic process contributes to the development of many teachers in terms of technology use.

In the study, the education process in the COVID-19 pandemic was evaluated from the points of students. The findings are given in (Table 3).

Table 3. Assessment of COVID-19 pandemic process from the points of students

\begin{tabular}{|c|c|c|c|c|}
\hline Category & Theme & Sub-theme & $\mathrm{f}$ & $\%$ \\
\hline \multirow{8}{*}{ Negative } & \multirow{5}{*}{$\begin{array}{l}\text { Social and } \\
\text { psychological effect }\end{array}$} & Boredom & 69 & 29.1 \\
\hline & & Decreased sense of belonging to school & 10 & 4.2 \\
\hline & & Inadequate interaction & 13 & 5.5 \\
\hline & & Motivation loss & 36 & 15.2 \\
\hline & & Digital addiction & 6 & 2.5 \\
\hline & \multirow{3}{*}{ Educational effect } & Inefficiency of education & 29 & 12.2 \\
\hline & & Adaptation problem to distance education & 16 & 6.8 \\
\hline & & Technological infrastructure inadequacy & 7 & 3.0 \\
\hline \multirow{4}{*}{ Positive } & \multirow{2}{*}{$\begin{array}{l}\text { Social and } \\
\text { psychological effect }\end{array}$} & Supporting skill development & 5 & 2.1 \\
\hline & & Awareness of the value of interaction & 6 & 2.5 \\
\hline & \multirow{2}{*}{ Educational effect } & Time management/effectiveness & 29 & 12.2 \\
\hline & & Awareness of distance education & 11 & 4.7 \\
\hline
\end{tabular}

When the findings in Table 3 are analysed, it was determined that the education process in COVID-19 pandemic has positive and negative aspects in terms of social/psychological effects and distance education for students. The teachers stated their negative opinions that the students were experiencing boredom $(29.1 \%)$ in the pandemic process. However, the teachers stated that distance education in the pandemic process is positive in terms of students' time management/efficiency (12.2\%). Sample opinions on the negative effects of the COVID-19 pandemic process for students are given below:

T-18: They are very bored. Intense assignments given to keep them involved with the system and staying at home have overwhelmed the students. T-45: Some of the students spend the process in holiday mode. T-64: Children are overwhelmed by the uncertainty and the fact that they cannot leave home at all. T-68: It is a process that they lack the 
education and socialization processes that the school provides for them. T-81: Due to the accumulated or pre-supplied materials left in schools, our students experience a shortage of materials in their homes. T-102: I think the epidemic caused students to order away from school. T-121: It is a very important deficiency in terms of affective side of education because the students cannot share the same environment with the teachers they love and respect. T-165: I think it is inadequate. This process made students more dependent on computers and the Internet. T-206: Students moved away from school because of computer games. T-224: Students' being more dependent on technology and screens and increasing individuality will bring along negativities.

Sample opinions on the positive effects of the COVID-19 pandemic process for students are given below:

T-15: The student learned that education is not only at school. T-16: Online trainings continue efficiently for "especially" students with self-discipline. Awareness raising is important in this process. T-27: The process was informative as regards to showing the future status of teaching. T-60: Our students gained an understanding of the value of the school to a great extent. T-61: The students internalized the value of their schools. T-158: Is technology helpful or harmful? They found the answer to the question. Technology is useful and makes our life easier. T-230: I think distance education given through EBA will be beneficial for students.

In the study, the education process during COVID-19 pandemic was evaluated in terms of teacher-parent relationship. The findings are given in (Table 4).

Table 4. Opinions on teacher-parent relationship in the COVID-19 pandemic process

\begin{tabular}{lllll}
\hline Category & Theme & Sub-theme & f & $\%$ \\
\hline \multirow{3}{*}{ Positive } & \multirow{3}{*}{ Communication } & Increased mutual dialogue & 66 & 27.9 \\
& & Increase in cooperation with parents & 54 & 22.8 \\
& \multirow{2}{*}{ Negative } & Parents empathize with teachers & 37 & 15.6 \\
\hline \multirow{2}{*}{ Communication } & Decreased mutual dialogue & 49 & 20.7 \\
& & Decrease in cooperation & 31 & 13.0 \\
\hline
\end{tabular}

When the findings in Table 4 are analysed, it was determined that the teachers had positive and negative opinions about the communication between the teacher and the parents during the pandemic process. In the pandemic process, it was determined that the dialogue between the teacher and the parents $(27.9 \%)$ increase in cooperation with parents $(22.8 \%)$ and parents' ability to empathize with teachers $(15.6 \%)$ increased. However, the results of the research also showed that there are negative views. Examples of the negative effects of the COVID-19 pandemic process in terms of teacher-parent are given below:

T-3: Parents feel bored with both the children staying at home and the teachers who are constantly searching. T-16: There is a communication gap between parents and teachers. T-31: Parents refuse cooperation and practices. T-66: Student-parent conflicts may also increase. T-86: I would expect parents to participate more actively. T-108: Parents' demands have steadily increased in the distance education process. T-120: We have communication problems. T-135: The majority of parents avoid being involved in this process and taking over responsibility. T-153: Parents put pressure on teachers about distance education. T-187: Many parents have stopped communicating with us.

Examples of the positive effects of the COVID-19 pandemic process in terms of teacherparent are given below: 
T-5: Parents developed empathy for teachers. T-13: Our parents may have understood that the education of their children is not only the teacher's job but also theirs. T-24: Our communication with the parents continues as if we were a family member. T-174: I think parents understand teachers better. T-189: Parents were able to empathize with teachers by getting to know their children. T-217: In this process, when I evaluated from my point of view, teacher communication increased more, because our common point is our students.

In the research, teachers' concerns were determined in the direction of the progress of the COVID-19 pandemic in the world. The findings obtained are given in (Table 5).

Table 5. Teachers' concerns about the COVID-19 pandemic process

\begin{tabular}{lllll}
\hline Category & Theme & Sub-theme & $\mathrm{f}$ & $\%$ \\
\hline \multirow{4}{*}{ There is a concern } & \multirow{3}{*}{ Health } & Increased mortality & 30 & 12.7 \\
& & Uncertainty & 38 & 16.0 \\
& & Psychological effect & 33 & 13.9 \\
& & Increase in pandemic & 43 & 18.2 \\
\cline { 2 - 5 } & \multirow{2}{*}{ Education } & Academic deficiency & 22 & 9.3 \\
& & School atmosphere interaction dimension & 27 & 11.4 \\
\cline { 2 - 6 } & Economy & Unemployment & 19 & 8.0 \\
\hline No concern & & 25 & 10.5 \\
\hline
\end{tabular}

When the findings in Table 5 are examined, it is determined that teachers have concerns about health, education, and economy. Teachers are mostly worried about the increase in pandemics for the healthcare area, $18.2 \%(f=43)$. For the field of education, $11.4 \%$ of teachers $(f=27)$ are worried about the loss of the school atmosphere interaction dimension. However, $10.5 \%$ (f $=25$ ) of the teachers who participated in the study stated that they did not have any concerns about the COVID-19 pandemic process. Sample opinions of teachers are given below:

T-13: I am very worried about the increased mortality and the fact that pandemic cannot be brought under control and can harm our loved ones. T-25: Future is not certain, there is uncertainty about it. T-44: I think that if this process extends, it will harm both students and teachers psychologically. T-71: Especially young children are deprived of play environments with their friends. So, I am concerned. T-116: The expansion of the virus' impact area makes me nervous. T-125: I think that students are falling behind academically. T-134: There is no equipment that can measure students literally in distance education. T-149: In formal education, teaching and learning is carried out by communication between teacher and student. However, distance education is limited to the screen. This situation raises anxiety for the education system. T-169: I think it will have psychological effects as well as a lot of losses of life. T-181: I am really afraid that education will be provided completely by distance education. T-225: It will be very difficult for students to get back to the school again, they will not integrate into the school easily. T-229: I am worried about the increase in the number of deaths.

\section{Discussion and Conclusion}

In this study, it was aimed to determine the teachers' views towards the effects of COVID-19 on the education process in Turkey. Teachers evaluated education-teaching in the COVID-19 pandemic process in terms of teacher, student, teacher-parent relationship, and teacher concerns. As a result of the research, it was found out that the teachers had positive and negative thoughts regarding the education process that took place due to the COVID-19 pandemic. Teachers expressed their negative views on competences regarding difficulty, 
uncertainty, economic losses, and deficiencies in education. In addition, it has been figured out that there are negative views regarding the poor interaction, unproductivity, technological infrastructure and lack of teacher competencies related to distance education, which occurred due to the COVID-19 pandemic. For the integration of technology into education, pedagogical competencies, attitudes, and equipped backgrounds of teachers should be very strong (Chen, 2010). In order for them to be successful in the distance education process, communication between student and teacher should be strong and feedback should be provided (Richardson et al., 2015). Determining student expectations is another factor that is effective in success (Cab1, 2018). The results of the research showed that teachers had positive thoughts about the development of skills, the use of technology, the continuity of education and the development of time management skills during the pandemic process. It can be said that teachers' responsibilities increase in order to prevent education systems from being affected by global problems and to fully realize the necessary technological integration. In reality, the pandemic process has evoked the increase in technological awareness in education systems (Iwai, 2020). Studies have shown that teachers are willing to use technology in education (Arslan \& Şendurur, 2017; Kafyulilo, Fisser \& Voogt, 2016). Research by Abed, Alyahya and Altameeme (2020) has shown that the use of technology gives positive results in the education process. The results of the research by Basilaia and Kvavadze (2020) highlighted that online education in Georgia during the COVID-19 pandemic process was found successful by students. According to Goh and Sanders (2020), differences in medical education will emerge after the COVID-19 pandemic and the use of technology will become the main component of medical education. said it would be fair to state that teachers' responsibilities for the integration of educational systems from global problems and technological integration have increased. In addition, education platforms that can be created by utilizing the experiences of individuals (doctor, teacher, manager etc.) who take an active role in pandemics can be useful.

In the research, the education process that took place due to the COVID-19 pandemic was examined in terms of the student. The results of the research showed that the COVID-19 pandemic process has social and psychological effects on students in the issues of boredom, decreased sense of belonging to the school, lack of interaction, loss of motivation and digital dependency. In addition, it was determined that the deficiencies that distance education will create in terms of affective are more than cognitive education. In the pandemic process, it is seen as an important deficiency that the students cannot get together with their friends in terms of social development, cannot play games, and are deprived of activities that support their social development. Today, in the regions where the rate of urbanization is high, the chances of children to play in their living environments are already very limited. Students meet these needs by playing with their friends at school, especially during breaks. It is thought that students do not have these opportunities in the distance education process. In addition to these, teachers stated that unproductivity, adaptation problem and lack of technological infrastructure affect the students negatively during distance education in the process. However, according to the opinions of the teachers, it was observed that this process had several positive effects on students regarding the issues like supporting students' skill development, appreciation, time management/efficiency skills and awareness levels. In the research conducted by Sintema (2020), the COVID-19 pandemic process also negatively affected the academic performance of students. Measures should be taken to minimize the effects of the education process on these negative issues. Online platforms, legal acts and regulations that will be prepared after the epidemic will enable faster adaptation to similar situations in the future (Basilaia \& Kvavadze, 2020). 
In the research, the education process in the COVID-19 pandemic was examined in terms of the teacher-parent relationship. The results of the research have shown that the education process in the COVID-19 pandemic positively affects the communication between the teacher and the parent in terms of increased mutual dialogue, improved cooperation, and empathy. That being said, some teachers stated that the process was negative in terms of mutual dialogue and cooperation. Family life is important in preventing students from being affected by the negative issues caused by the COVID-19 pandemic (Cao et al., 2020). For this reason, cooperation between teacher and parents should be established for controlling the crisis process and having a good rapport (Lunn et al. 2020). Additionally, teacher-parent communication has a positive effect on the education process (Erdoğan \& Demirkasımoğlu, 2010; Yalçın, Saltali \& Ateş, 2020). For this reason, it is thought that it will be beneficial to carry out activities to increase teacher-parent communication in order to prevent students to be influenced negatively in academic and psychological senses during the pandemic.

In the study, teachers' concerns were identified about the progress of the COVID-19 pandemic in the world. The teachers stated that they had concerns about the increased mortality, uncertainties, and psychological effects. It can comfortably be uttered herein that he COVID-19 pandemic process will cause significant changes in our economic, health and social lives (Haleem, Javaid \& Vaishya, 2020). Kim, Kim, Peck and Jung (2020) determined that the spread and mortality rates of the virus will increase as a result of their research based on mathematical modelling. Studies have shown that COVID-19 pandemic has both fatal and psychological effects (Xiao, 2020). Wang et al. (2020) stated that COVID-19 pandemic will have a high degree of psychological effects on people in China. Cao et al. (2020) found that the spread of pandemics in China caused serious anxiety disorders in university students. Determining and monitoring the psychological effects of pandemic diseases on both society and individuals are particularly important for crisis management (Ho, Chee, \& Ho, (2020). Furthermore, mental problems will cause students' learning motivation to decrease (Piumatti, 2018). Therefore, the concerns of teachers who will be effective in shaping the social structure after the epidemic process should be taken into consideration. In this study, it was witnessed that teachers hold concerns about education in terms of academic deficiency and loss of school atmosphere and about the increase in unemployment, an issue regarding economy. According to the World Health Organization (2020), COVID-19 pandemic will negatively affect both the social and economic structures of countries. Taking economic measures is vital for ensuring social trust (Bostan et al., 2020). Schools are places where education takes place and they provide a suitable platform for communication between and amongst individuals. They also provide psychological counselling services for students (Wang et al. 2020). For this reason, it is crucial for students to attend school and be a part of the ethos. Moreover, preventing teachers' economic concerns will increase the quality of education during the pandemic process and after it.

\section{Suggestions}

In conclusion, the following suggestions can be made in the direction of the opinions of the teachers working in different branches participating in this research:

- In order for distance education to be conducted in a healthy and continuous manner, nonstop and high-speed access to the internet to the residences where students will receive this service should be ensured.

- Expert support should be provided to teachers who consider themselves insufficient in terms of technological knowledge and equipment in distance education. 
- The provision of these devices by the National Ministry of Education to students who do not have computers and laptops in their houses due to the financial in capabilities will enable the education process to continue without any setback during the pandemic process.

- The participants of this study are teachers. Similar studies may be conducted with the participation of students and parents.

\section{Limitations of the Research}

- Teachers in the study group of the research may not have enough experience in distance education.

- During the data collection process, the forms might not have reached the teachers actively involved in distance education.

\section{References}

Abed, S., Alyahya, N., \& Altameem, A. (2020). IoT in Education: Its Impacts and Its Future in Saudi Universities and Educational Environments. In First International Conference on Sustainable Technologies for Computational Intelligence (pp. 47-62). Springer, Singapore.

Acar, Y. (2020). The novel coronavirus (cov1d-19) outbreak and impact on tourism activities. Journal of Contemporary Tourism Research, 4(1), 7-21. https://doi.org/10.32572/guntad.703410

Arslan, S., \& Şendurur, P. (2017). Investigation of changes in factors affecting the technology integration in education. Mehmet Akif Ersoy University Journal of Education Faculty, 43, 25-50.

Ayittey, F.K., Ayittey, M.K., Chiwero, N.B., Kamasah, J.S., \& Dzuvor, C. (2020). Economic impacts of Wuhan 2019-nCoV on China and the world. J Med Viro., 92, 473-475. https://doi.org/10.1002/jmv.25706

Bakioğlu, B., Çevik, M. (2020). Science Teachers' Views on Distance Education in the COVID-19 Pandemic Process. Turkish Studies, 15(4), 109-129. https://dx.doi.org/10.7827/TurkishStudies.43502

Basilaia, G., \& Kvavadze, D. (2020). Transition to Online Education in Schools during a SARS-CoV-2 Coronavirus (COVID-19) Pandemic in Georgia. Pedagogical Research, 5(4), em0060. https://doi.org/10.29333/pr/7937

Bostan S., Erdem R., Öztürk Y.E., Kılıç T., Yılmaz A. (2020). The Effect of COVID-19 Pandemic on the Turkish Society. Electron J Gen Med., 17(6), em237. https://doi.org/10.29333/ejgm/7944

Cab1, E. (2018). Teaching computer literacy via distance education: Experiences of the instructors. Başkent University Journal of Education,5(1), 61-68. http://buje.baskent.edu.tr/index.php/buje/article/view/93

Cao, W., Fang, Z., Hou, G., Han, M., Xu, X., Dong, J., \& Zheng, J. (2020). The psychological impact of the COVID-19 epidemic on college students in China. Psychiatry Research, 287, 1129-1134. https://doi.org/10.1016/j.psychres.2020.112934

Chen, R. J. (2010). Investigating models for preservice teachers' use of technology to support

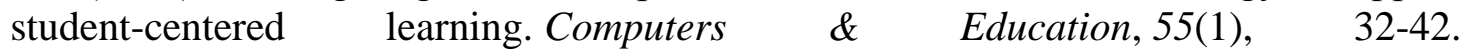
https://doi.org/10.1016/j.compedu.2009.11.015

Cohen, L., Manion, L. \& Morrison, K. (2007). Research methods in education (5th Ed.). London and New York: Routledge Falmer. 
Creswell, J. W. (2007). Qualitative inquiry \& research design: Choosing among five approaches (2nd Edition) SAGE Publications: USA.

Çobanoğlu, N . (2020). Ethics of Individual, Professional, Social, Scientific and Politic is Questioned By COVID-19 Pandemi. Anatolian Clinic the Journal of Medical Sciences, 25(Supplement 1), 36-42. https://doi.org/10.21673/anadoluklin.709891

Erdoğan, Ç., \& Demirkasımoğlu, N. (2010). Teachers' and school administrators' views of parent involvement in education process. Educational Administration: Theory and Practice, 3(3), 399-431.

Fraenkel, J. R., Wallen, N. E. \& Hyun, H. H. (2012). How to design and evaluate research in education (7. ed). New York: McGraw-Hill.

Goh P., \& Sandars J. (2020). A vision of the use of technology in medical education after the COVID-19 pandemic. MedEdPublish, 9(1), 1-8. https://doi.org/10.15694/mep.2020.000049.1

Haleem, A., Javaid, M., \& Vaishya, R. (2020). Effects of COVID 19 pandemic in daily life. Current medicine research and practice, 10.1016/j.cmrp.2020.03.011. Advance online publication. https://doi.org/10.1016/j.cmrp.2020.03.011

Ho, C. S., Chee, C. Y., \& Ho, R. C. (2020). Mental health strategies to combat the psychological impact of COVID-19 beyond paranoia and panic. Ann Acad Med Singapore, 49(1), 1-3.

Iwai, Y. (2020) 'Online Learning during the COVID-19 Pandemic: What do we gain and what do we lose when classrooms go virtual?', Scientific American. Available at: https://blogs.scientificamerican.com/observations/online-learning-during-the-covid19-pandemic/ (Accessed: 20 April 2020).

Kafyulilo, A., Fisser, P., \& Voogt, J. (2016). Factors affecting teachers' continuation of technology use in teaching. Education and Information Technologies, 21(6), 15351554. https://doi.org/10.1007/s10639-015-9398-0

Kanoglu, F., \& Saglam, K. (2020). Views of academic and administrative staff on flexible working system during the covid-19 pandemic period. Ankara International Congress on Scientific Research - III, 12-31. Ankara: ISPEC Publications.

Karakaya, F., Arik, S., Cimen, O., \& Yilmaz, M. (2020). Investigation of the views of biology teachers on distance education during the COVID-19 pandemic. Journal of Education in Science, Environment and Health (JESEH), 6(4), 246-258. https://doi.org/10.21891/jeseh.792984

Kim, S., Kim, Y. J., Peck, K. R., \& Jung, E. (2020). School Opening Delay Effect on Transmission Dynamics of Coronavirus Disease 2019 in Korea: Based on Mathematical Modeling and Simulation Study. Journal of Korean medical science, 35(13):e143. https://doi.org/10.3346/jkms.2020.35.e143

Leduc, S., \& Liu, Z. (2020). The Uncertainty Channel of the Coronavirus. FRBSF Economic Letter, 2020(07), 1-05.

Lunn, P. D., Belton, C. A., Lavin, C., McGowan, F. P., Timmons, S., \& Robertson, D. A. (2020). Using Behavioral Science to help fight the Coronavirus. Journal of Behavioral Public Administration, 3(1), 1-35. https://doi.org/10.30636/jbpa.31.147

Madigan, M.T., Bender, K.S., Buckley, D.H., Sattley, W. M., \& Stahl, D.A. (2019). Brock Biology of Microorganisms. Pearson Education Limited, USA.

Matteo, L., \& Pianta, M. (2020). The Coming Coronavirus Crisis: What Can We Learn?. Intereconomics, 55(2), 98-104. https://doi.org/10.1007/s10272-020-0878-0

Miles, M.B., \& Huberman, A.M. (2015). Qualitative data analysis (1. ${ }^{\text {st }}$ (Ed. S. Altun Akbaba \& A. Ersoy). Ankara: Pegem Pub. 
Ministry of Health (2020). Suggestions for Avoiding COVID-19 (New Coronary Virus Disease). From:https://covid19bilgi.saglik.gov.tr/tr/covid-19-yeni-koronavirushastaligi-na-yakalanmamak-i-cin-oneriler

Özer, M . (2020). Educational Policy Actions by the Ministry of National Education in the times of COVID-19 Pandemic in Turkey. Kastamonu Education Journal, 28(3),11241129. https://doi.org/10.24106/kefdergi.722280

Piumatti, G. (2018). Motivation, health-related lifestyles and depression among university students: A longitudinal analysis. Psychiatry research, 260, 412-417. https://doi.org/10.1016/j.psychres.2017.12.009

Rani, R. (2020). The Impact of Corona Virus on Indian Economy. Studies in Indian Place Names, 40(60), 3618-3626.

Rasmussen, S.A., Smulian, J.C., Lednicky, J.A., Wen, T.S., \& Jamieson, D.J. (2020). Coronavirus disease 2019 (COVID-19) and pregnancy: what obstetricians need to know. Am J Obstet Gynecol. https://doi.org/10.1016/j.ajog.2020.02.017

Reece, J.B, Urry, L.A., Cain, M.L., Wasserman, S.A., Minorsky, P.V. \& Jackson, R.B. (2017). Campbell Biology (Eleventh Edition). Pearson Education, USA.

Richardson, J.C., Koehler, A., Besser, E., Caskurlu, S. Lim, J., \& Mueller, C. (2015). Conceptualizing and investigating instructor presence in online learning environments. International Review of Research in Open and Distributed Learning, 16(3), 256-297. https://doi.org/10.19173/irrodl.v16i3.2123

Saglam, K., Kanoglu, M. F., Guler, M. A., \& Ceyhan, Ş., (2020). Determining the organizational commitment levels of health workers during the covid-19 pandemic process. Ankara International Congress on Scientific Research - III, 11-13. Ankara: ISPEC Publications.

Sintema, E. J. (2020). Effect of COVID-19 on the Performance of Grade 12 Students: Implications for STEM Education. Eurasia Journal of Mathematics, Science and Technology Education, 16(7), em1851. https://doi.org/10.29333/ejmste/7893

Taylor, M.R., Simon, E.J., Dickey, J.L., Hogan, K., Reece, J.B. (2018). Campbell Biology: Concepts \& Connections. Pearson Education, USA.

The Council of Higher Education (YÖK) (2020, 03 29). Press briefing. From: www.yok.gov.tr/Sayfalar/Haberler/2020/universitelerde-uygulanacak-uzaktanegitime-iliskin-aciklama.aspx.

Tümkan, F. \& Tümkan, Ş. (2020). During the Pandemic Evaluating The Impact of the Change Caused to Elementary School Education In Light of the Compulsory Suspension of Education. Turkish $\quad$ Studies, $\quad 15(4), \quad 1163-1184$. https://dx.doi.org/10.7827/TurkishStudies.44411

UNESCO (2020, March 27). Teacher Task Force calls to support 63 million teachers touched by the COVID-19 crisis. UNESCO. From: https://en.unesco.org/news/teacher-taskforce-calls-support-63-million-teachers-touched-covid-19-crisis

Wang, C., Pan, R., Wan, X., Tan, Y., Xu, L., Ho, C.S., \& Ho, R. C. (2020). Immediate psychological responses and associated factors during the initial stage of the 2019 coronavirus disease (COVID-19) epidemic among the general population in China. International Journal of Environmental Research and Public Health, 17(5), 1705-29. https://doi.org/10.3390/ijerph17051729

Wang, G., Zhang, Y., Zhao, J., Zhang, J., \& Jiang, F. (2020). Mitigate the effects of home confinement on children during the COVID-19 outbreak. The Lancet, 395(10228), 945-947. https://doi.org/10.1016/S0140-6736(20)30547-X

Wang, Y., Wang, Y., Chen, Y., \& Qin, Q. (2020). Unique epidemiological and clinical features of the emerging 2019 novel coronavirus pneumonia (COVID-19) implicate 
special control measures. Journal of medical virology.1-9. https://doi.org/10.1002/jmv.25748

Williams, S. N., Armitage, C. J., Tampe, T., \& Dienes, K. (2020). Public perceptions and experiences of social distancing and social isolation during the COVID-19 pandemic: A UK-based focus group study. medRxiv. https://doi.org/10.1101/2020.04.10.20061267

Wong, J., Goh, Q. Y., Tan, Z., Lie, S. A., Tay, Y. C., Ng, S. Y., \& Soh, C. R. (2020). Preparing for a COVID-19 pandemic: a review of operating room outbreak response measures in a large tertiary hospital in Singapore. Canadian Journal of Anesthesia/Journal canadien d'anesthésie, 1-14. https://doi.org/10.1007/s12630-02001620-9

World Health Organization (WHO) (2020). WHO Director-General's Remarks at the Media Briefing on 2019-nCoV on 11 February 2020. From: https://www.who.int/dg/speeches/detail/who-director-general-s-remarks-at-the-mediabriefing-on-2019-ncov-on-11-february-2020

Xiao, C. (2020). A novel approach of consultation on 2019 novel coronavirus (COVID-19)related psychological and mental problems: Structured letter therapy. Psychiatry investigation, 17(2), 175-176. https://doi.org/10.30773/pi.2020.0047

Yalçin, O.M., Saltali, N.D., \& Ateş, M.A. (2020). Searched Parent Profile in Preschool Education. International Journal of Social and Educational Sciences, 2(2), 1-23. https://dergipark.org.tr/tr/pub/usbed

Yamamoto, G.T. (2020). The Coronavirus and the Rising of Online Education. Journal of $\begin{array}{lll}\text { University } & \text { Research, } & \text { 25-34. }\end{array}$ https://dergipark.org.tr/tr/pub/uad/issue/53721/702735

Yildirim, A., \& Şimşek, H. (2011). Qualitative research methods in the social science. Ankara: Seçkin Pub.

Yilmaz, M., Çimen, O., Karakaya, F., \& Üçüncü, G. (2018).The situations causing examination anxieties towards human anatomy and physiology topics of preschool teacher candidates and factors reducing anxiety. Anatolian Journal of Teacher, 2(1), 1-18. http://dergipark.org.tr/tr/pub/aod/issue/37865/432332 